The University of Akron

\title{
IdeaExchange@UAkron
}

Proceedings from the Document Academy

University of Akron Press Managed

June 2017

\section{The Biographer Walks Through the Remnants of Modernism}

Tessa Withorn

Indiana University, Bloomington, tewithor@umail.iu.edu

Please take a moment to share how this work helps you through this survey. Your feedback will be important as we plan further development of our repository.

Follow this and additional works at: https://ideaexchange.uakron.edu/docam

\section{Recommended Citation}

Withorn, Tessa (2017) "The Biographer Walks Through the Remnants of Modernism," Proceedings from the Document Academy: Vol. 4 : Iss. 1 , Article 3.

DOI: https://doi.org/10.35492/docam/4/1/3

Available at: https://ideaexchange.uakron.edu/docam/vol4/iss 1/3

This Article is brought to you for free and open access by University of Akron Press Managed at IdeaExchange@UAkron, the institutional repository of The University of Akron in Akron, Ohio, USA. It has been accepted for inclusion in Proceedings from the Document Academy by an authorized administrator of

IdeaExchange@UAkron.For more information, please contact mjon@uakron.edu, uapress@uakron.edu. 
Dear reader, do you feel the weight of this book in your hands?

What if I told you there was a place in Belgium that held

nothing but index cards and pigeon shit. In the basement of the Mundaneum,

enter the lecture theater-dimly-lit, steeply-ranked-between two busts

decorated in floral wreaths.

What remains of their disciplines

—Les Amis du Palais Mondial_gather each year to honor their fathers.

In Otlet's Mundaneum, everything has a place and everyone can speak the universal language.

What if I told you a card catalog could stretch the length of the world?

Open a drawer and each leaf bears nothing but the essence of a thing.

In a perfect world, knowledge is not confined in books but hyperlinked.

And there really is a tree somewhere between the Tigris and Euphrates.

I submit the leaf and fig as evidence, every single fact in the world written down.

Reader, you are the only one who can attest to things I have experienced and written down. 


\section{Notes}

Some of the language and imagery in this poem is borrowed from the following two sources:

Rayward, Boyd W. (1991). "The Case of Paul Otlet, Pioneer of Information Science, Internationalist Visionary: Reflections of Biography." Journal of Librarianship and Information Science 23. pp. 135-145.

Alle Kennis van de Wereld (Biography of Paul Otlet). (1998). Documentary narrated by W. Boyd Rayward. Available at: https://youtu.be/KLX2OGw31Oo.

The concept of reader as witness originates from Muriel Rukeyser's 1949 book The Life of Poetry:

"Audience" or "reader" or "listener" seems inadequate. I suggest the old word "witness," which includes the act of seeing or knowing by personal experience, as well as the act of giving evidence. The overtone of responsibility in this word is not present in the others... announcing with the poem that we are about to change, that work is being done on the self. (p. 175 in 1996 edition) 